\title{
Impacts of insect outbreaks on tree mortality, productivity, and stand development
}

\author{
David A. MacLean ${ }^{1}$
}

\begin{abstract}
The impacts of insect outbreaks on tree mortality, productivity, and stand development in Canada are reviewed, emphasising spruce budworm (Choristoneura fumiferana (Clemens), Lepidoptera: Tortricidae) and mountain pine beetle (Dendroctonus ponderosae Hopkins, Coleoptera: Curculionidae). Reduced growth and survival are a function of insect population and defoliation level. It is feasible to make short-term (annual) predictions of insect population and defoliation based upon sampling, but long-term, multi-year predictions are problematic. Given the historical record, it is expected that outbreaks will occur with relatively predictable frequency and basic host relationships and abiotic constraints will not change dramatically. However, the precision of predictions at fine scales is variable and reduced over time. Relationships between tree growth reduction, survival, and cumulative defoliation or beetle population level are available for major insect species. Understanding insect outbreak effects hinges on mortality, changes in interspecies competition, regeneration, and succession. Altered stand dynamics caused by insects can be interpreted for indicators such as wildlife habitat, old forest, riparian buffer cover, viewscapes, and connectivity. Anthropogenic changes are altering impacts via range expansions, northward shifts, and changes in forest composition. We can better understand effects of insect outbreaks and how best to ameliorate damage through a combination of empirical permanent plot studies, modelling, and manipulative experiments.
\end{abstract}

\section{Introduction}

Ecological and economic effects of insect outbreaks on tree resources are two differing but complementary aspects of the short-term and long-term biological effects of insect feeding. The most damaging insects in Canada are typically defoliators, which feed on the foliage of trees or other plants, and bark beetles, the most damaging of which feed on the phloem and cambium. The primary effects of insects on trees are: (1) growth reduction, whereby the tree reduces stem wood and branch growth and typically reduces the root system, in favour of rebuilding defoliated foliage capacity; (2) cessation of seed production; (3) tree mortality, when the defoliation or beetle attacks overwhelm the tree's ability to survive; and (4) regeneration or successional processes, whereby existing host species regeneration may be damaged and other species regeneration and vegetation may be promoted by lessened competition.
If trees survive the insect feeding, then growth reduction may be a temporary slowing-down of stem wood production and of stand timber volume increment. In fact, residual trees often enter into a phase of accelerated growth due to release (e.g., Axelson et al. 2009, 2010 for mountain pine beetle (Dendroctonus ponderosae Hopkins, Coleoptera: Curculionidae); Hennigar and MacLean 2010 for spruce budworm (Choristoneura fumiferana (Clemens), Lepidoptera: Tortricidae). Mortality, on the other hand, removes growing stock (trees) from the stand, to reduce both current yield and the future rate of growth increment. Both ecological and economic effects of insect outbreaks on tree resources hinge upon changes to trees and forests resulting from defoliation or beetle effects - typically termed "impacts". Severity of growth reduction and mortality in turn hinge upon the insect outbreak severity (which is a function of insect population level), extent, and duration (years), as well as on

Received 23 November 2014. Accepted 15 March 2015. First published online 4 June 2015.

D. A. MacLean, ${ }^{1}$ Faculty of Forestry and Environmental Management, University of New Brunswick, P.O. Box 4400, Fredericton, New Brunswick, Canada E3B 5A3

${ }^{1}$ Corresponding author (e-mail: macleand@unb.ca).

Langor, D.W. and Alfaro, R.I. (eds.) Forest Entomology in Canada: Celebrating a Century of Science Excellence doi: $10.4039 /$ tce. 2015.24 
the feeding ecology of the insect and host species vulnerability and interactions. For example defoliators such as spruce budworm generally feed on only a portion of non-vital foliar tissues (current year foliage only) and so take years to kill a tree; hemlock looper, Lambdina fiscellaria Guenée (Lepidoptera: Geometridae), feeds on all foliage age classes, and kills trees in 1-2 years; the mountain pine beetle, Dendroctonus ponderosae Hopkins (Coleoptera: Curculionidae), reproductive strategy is as a virulent host-killer, where host death is required for successful reproduction, and is accomplished by introduction of fungal symbionts to the phloem and cambium, with subsequent spread to the sapwood; and spruce beetle, Dendroctonus rufipennis Kirby (Coleoptera: Curculionidae), typically relies on previous disturbance (other insects, windthrow, change in water table, slash from forestry) to flourish.

The key to projecting effects of insect outbreaks on tree resources is definition of relationships between growth reduction versus defoliation level and mortality (or survival) versus defoliation level, and building these into projections of stand dynamics that include competition processes (Erdle and MacLean 1999). For beetles and other non-defoliators, the relationships would pit growth and survival versus insect population level. For defoliators, a further relationship could relate defoliation to population level, but most models and decision support systems use defoliation as a driving variable. In many cases, vulnerability (growth reduction and mortality) differs as a function of tree and stand variables such as species, age, and site quality.

Erdle and MacLean (1999) described quantitative assessment of pest impacts as requiring four steps that can be conceptually viewed as a set of relationships in which the dependent variable from one relationship becomes the independent variable that drives the next relationship. The four steps are: (1) forecasts of insect population level over time (years), usually as a possible scenario based upon past outbreaks and/or population modelling, and including effects of possible control alternatives on those populations; (2) meaningful expressions of the nature and severity of damage inflicted on the tree or stand (e.g., defoliation level) as a function of insect population level; (3) effects on tree and stand development (e.g., growth reduction, reduced survival, and deterioration of form, perhaps with additional effects on regeneration and long-term successional changes) as a function of damage level; and (4) effects on forest (landscape) development as a function of the accumulated stand-level impacts.

The key to assessing and predicting effects of insect outbreaks on tree resources is understanding their direct and indirect effects on stand development. This is essentially an alteration of perceived "normal" (i.e., undefoliated or unattacked) stand development processes of growth, competition, death, regeneration, and succession, so simulating insect effects can be thought of as a marginal change in the expected development process - e.g., a reduced growth rate or an increased mortality rate for host trees, or an increased growth rate for non-host trees, or an increased rate of blowdown (wind-caused mortality) resulting from stand opening. However, an important contemporary concept is that in most ecosystems, especially northern forest ecosystems, disturbance is a normative driver of ecosystem development, function, and sustainability. There are also interactions between disturbance types, for example, spruce budworm and fire (Stocks 1987; Péch 1993; Payette et al. 2000; Fleming et al. 2002), mountain pine beetle and fire (Axelson et al. 2009, 2010), spruce budworm and wind-caused mortality (Taylor and MacLean 2009), and insect damage and root rots (Ostaff 1983). Payette et al. (2000) documented the impact of combined insect and fire disturbances translating into a dramatic decrease in post-fire tree regeneration of the forest, inducing a shift to lichen woodland.

The objective of this paper is to review the science of impacts of insect outbreaks in Canada on tree mortality, productivity, and stand development. Emphasis is on the major insects, namely spruce budworm, mountain pine beetle, and forest tent caterpillar, Malacosoma disstria Hübner (Lepidoptera: Lasiocampidae), but I will include some information about other insects such as hemlock looper, balsam fir sawfly (Neodiprion abietis (Harris), Hymenoptera: Diprionidae), western spruce budworm (Choristoneura occidentalis (Walsingham), (Lepidoptera: Tortricidae)), jack pine budworm (Choristoneura pinus Freeman, (Lepidoptera: Tortricidae)), and spruce beetle. The main focus is on Canadian contributions, and given that future impacts will be affected by potential future 
changes in outbreak severity, I will end with a discussion of whether anthropogenic changes are altering effects of outbreaking insects.

\section{Scale of natural disturbances in Canada's forests}

Insect outbreaks, along with fire, are the two major natural disturbances in Canadian forests. The relative predominance of the two disturbance types and the specific insect undergoing an outbreak varies among regions and time periods. Much of the boreal forest is driven by fire disturbance, with insect-caused disturbance secondary, whereas major outbreaks of spruce budworm in eastern boreal or Acadian forest in the 1970s-1980s or mountain pine beetle in the 1990s-2000s in ecozones in British Columbia were clearly the dominant disturbances at those times and places. Impacts of insects and other disturbances are specific, and their importance varies among ecozones across Canada. In Atlantic Canada, insect disturbances predominate. Although wind, especially hurricanes, is a third major natural disturbance that can locally be very important, it is small in comparison to the extent and effects of insect outbreaks and fire. For example, Bouchard et al. (2009) examined standreplacing windthrow on 3000000 ha of boreal forest in eastern Québec, and concluded that windthrow affected $0.0255 \%$ per year. Their results suggested that stand-replacing windthrow is difficult to predict because it is primarily associated with random occurrence of exceptional windstorms (Bouchard et al. 2009). The important point here is that insect disturbances in forest are significant, predominate in certain ecozones and time periods, and even more so when they interact with other disturbances.

The following statistics about occurrence of fire and insect outbreaks in Canada, from the Canadian National Forestry Database (Canadian Council of Forest Ministers 2014), help put the scope of impacts in perspective. Forest area burned in Canada from 1990 to 2012 averaged $2800000 \mathrm{ha} / \mathrm{year}$, with a range of $626000 \mathrm{ha}$ (2001) to 7100000 ha in 1995. The range of area burned per year in Canada from "good" fire years (small area burned) to "bad" fire years (large area burned) typically exceeds 10 times, as a function primarily of annual weather conditions. The number of fires per year varies much less,
Table 1. Summed area in Canada from 1975-2000 with moderate-severe defoliation (30-100\%) or beetle-killed trees (data from National Forestry Database, Canadian Council of Forest Ministers 2014).

\begin{tabular}{lrr}
\hline Insect & Area (ha) & $\%$ \\
\hline Spruce budworm & 450668000 & 64 \\
Jack pine budworm & 13948000 & 2 \\
Mountain pine beetle & 2730000 & 0 \\
Hemlock looper & 1550000 & 0 \\
Forest tent caterpillar & 189242000 & 27 \\
Gypsy moth & 1807000 & 0 \\
Other insects (36 species) & 49390000 & 7 \\
Total & 709336000 & 100 \\
\hline
\end{tabular}

During this period, there was a major outbreak of spruce budworm in eastern Canada and the mountain pine beetle outbreak in western Canada was still increasing. Influence of insects depend upon their outbreak status in a given time period.

averaging 7760/year in Canada from 1990 to 2012 (Canadian Council of Forest Ministers 2014). Large fires ( $>200$ ha in size) represent only $3 \%$ of fires in Canada, yet account for $\sim 97 \%$ of the total area burned (Stocks et al. 2003). Thus, area affected by fires in a given year is primarily influenced by weather and fire control response policies.

Insect disturbance is similar to fire in that major effects coincide with occurrence of large-scale outbreaks or fires. However, a major difference is the relative selectivity and periodicity of insect disturbances via known host and forest susceptibilities. In contrast, fire disturbance is largely driven by climate and to an extent by forest composition (fuel) factors. From 1975 to 2000, spruce budworm outbreaks were huge in eastern Canada, defoliating a summed area over 25 years exceeding $450000000 \mathrm{ha}$, almost two-thirds of the total area subjected to moderate-severe defoliation or beetle-killed trees in Canada (Table 1). Forest tent caterpillar defoliation caused the second largest summed area over 25 years of disturbance at 189000000 ha (27\%), however, this defoliation typically caused little tree mortality unless at severe levels on stressed trees. In contrast, mountain pine beetle does cause heavy mortality with occurrence; it killed trees over 2700000 ha (only $0.4 \%$ of the total area affected by insects) from 1975 to 2000 , but by 2005 , once the mountain pine beetle outbreak in British Columbia erupted, it was the predominant 
Fig. 1. Total area of 16000000 ha in Canada in 2005 with moderate-severe defoliation or beetle-killed trees (data from National Forestry Database, Canadian Council of Forest Ministers 2014). This period was during the peak of the 2000s mountain pine beetle outbreak in British Columbia, so mountain pine beetle was the dominant insect and, in contrast with Table 1, spruce budworm only defoliated $4 \%$ of the area affected.

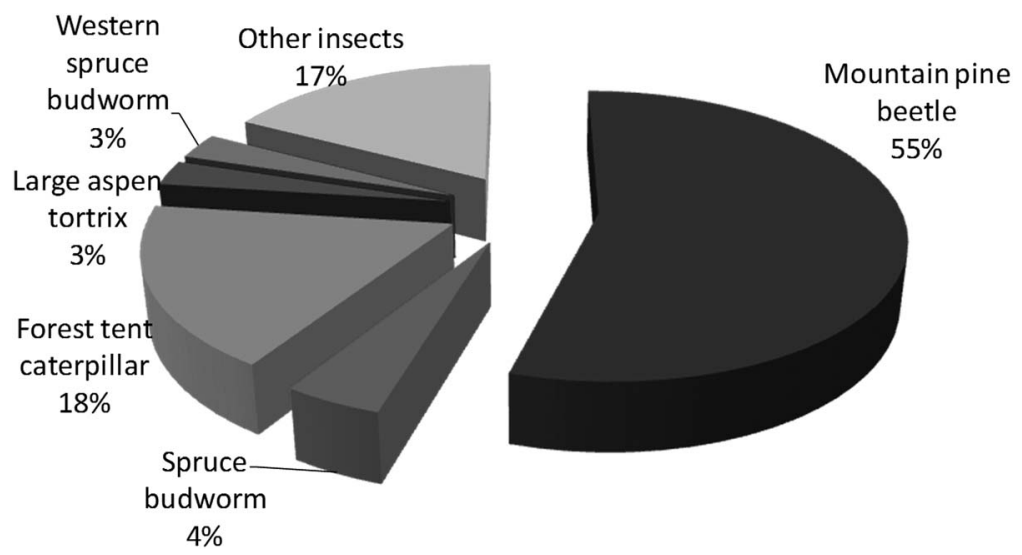

cause of insect disturbances in Canada, at $55 \%$ of the total 16000000 ha affected that year. By this time spruce budworm and forest tent caterpillar outbreaks, respectively, defoliated only $4 \%$ and $18 \%$ of the total area (Fig. 1).

Over the 1975-2012 period currently reported by the national forestry database (Canadian Council of Forest Ministers 2014), the annual area of moderate-severe defoliation and beetle-killed trees in Canada was at a maximum of 69000000 ha in 1977. Spruce budworm outbreaks were at their maximum extent of 52000000 ha in 1975 , declined to 12000000 ha in 1986,930000 ha in 1997, and ranged from 714000 to 4400000 ha from 1998 to 2012. Mountain pine beetle-caused mortality covered a maximum of 10000000 ha in 2007. The other most important insects in Canada included forest tent caterpillar which defoliated up to 24200000 ha in 1977, and jack pine budworm which defoliated a maximum of 5800000 ha in 1985.

The area affected by insect outbreaks in a given year depends on the outbreak status of each of the primary insect pests, which typically build up over several years, peak, and then decline, plus the reduction of insect populations by control measures (use of insecticides or other pest management strategies). Knowing area defoliated or of beetle-killed trees is the first step to estimating impacts. Although management efforts usually affect only a minor part of the outbreak range in most jurisdictions, exceptions include extensive insecticide use against spruce budworm in New Brunswick in the 1970s-1980s, and current mountain pine beetle management efforts in Alberta. In Alberta, all of the mountain pine beetle range is subject to triage assessment, half receives a treatment of some sort, and a zero tolerance policy is pursued in the "leading edge zone", about one-quarter of the range (Alberta Sustainable Resource Development 2007).

Several studies have examined temporal and spatial patterns of spruce budworm outbreaks. Blais (1983) delineated several distinct outbreak areas in eastern North America where outbreaks differed in time of onset or severity, with outbreaks historically tending to begin earlier in southwestern Québec and extending north and east. Using cluster analysis, Gray et al. (2000) divided past budworm defoliation in Québec into 25 representative patterns that differed in duration and severity. Royama et al. (2005) used spruce budworm population data to divide New Brunswick into three zones - north, middle, and south - with differing outbreak patterns. Gray and MacKinnon (2006) analysed spruce budworm outbreak defoliation across Canada, using $2 \times 2 \mathrm{~km}$ spatial resolution, and delineated 27 representative outbreak patterns. In Ontario, Candau et al. (1998) showed that budworm defoliation has occurred in three zones of frequent defoliation separated by longitudinally oriented 
corridors of lower frequency. Candau and Fleming (2005) developed two empirical statistical models to describe spatial variation in defoliation that revealed several relationships with bioclimatic conditions over the landscape. Variation in outbreak duration and severity is an important driver of all resulting impacts: growth reduction, tree survival, regeneration, succession, and ecological aspects such as resilience of the forest to recover because there are islands of relatively little change that serve as refuges or sources for colonisers assumed depleted by insect impacts.

Zhao et al. (2014) also used cluster analysis to analyse annual aerial survey records of defoliation by spruce budworm in New Brunswick from 1965 to 1992 , at four scales. Spruce budworm defoliated $92 \%$ of the 7400000 ha study area in at least one year. Zhao et al. (2014) grouped the 28 representative defoliation patterns, resulting from cluster analysis at $1 \times 1 \mathrm{~km}$ cell size, into five spruce budworm outbreak classes (termed A-E), which each covered $12-27 \%$ of the area. These differed substantially in defoliation duration and severity: classes A-B had only $1-3$ years of moderate (30-70\% of foliage removed) and severe (71-100\%) defoliation and $42-75 \%$ cumulative defoliation; class $\mathrm{C}$ had eight years and $127 \%$ cumulative defoliation; and classes D-E had 13-16 years and 170-208\% cumulative defoliation (Zhao et al. 2014). Distributions of area showed that with the exception of several small coastal areas, four or five of the outbreak classes occurred in all areas. Key messages from the various studies analysing spatial and temporal patterns are that there is wide spatial variation in spruce budworm outbreak patterns and large differences in outbreak duration and severity (cumulative defoliation). This is important in predicting effects or making management decisions that differentiate insecticide or salvage treatments based on severity or individual tree cutand-burn in the case of mountain pine beetle, and emphasises the need for accurate annual aerial survey or remote sensing-based defoliation or damage assessment.

A factor that needs to be accounted for in analysing effects of insect outbreaks is management intervention using insecticides. Because aerial application of insecticides has occurred on up to $50 \%$ of the moderate-severe defoliated areas in the mid-1970s in New Brunswick, it significantly reduced the defoliation that would have occurred without foliage protection (Kettela 1995). As a result, spatially referenced "without protection" defoliation estimates for New Brunswick were developed by Gray and MacKinnon (2007) and used by Zhao et al. (2014). These data used past annual information about insecticides used and their efficacy (i.e., defoliation reduction) (Kettela 1995) to estimate past annual defoliation levels, had there been no insecticide spraying (Gray and MacKinnon 2007). This permitted analyses of spruce budworm outbreaks patterns uninfluenced by past insecticide use. Insecticide use is an important topic to consider in assessment of impacts, because for some insects, it is an available approach to reduce impacts on mortality and stand development, if there is sufficient political will and funding to do so. From 1990 to 1999, 3500000 ha were sprayed with insecticides in Canada, $72 \%$ of which was using the biological insecticide Bacillus thuringiensis kurstaki Berliner (Bacillaceae) (Btk) (Canadian Council of Forest Ministers 2014). Use of insecticides varies considerably among provinces, and is not an option for some insects such as mountain pine beetle.

\section{Defoliation and insect population levels}

Step 1 of understanding insect impacts is elucidating outbreak temporal and spatial patterns. For foliovorous insects, the cumulative level of defoliation over the course of an outbreak primarily drives tree response. The severity of impacts during defoliator outbreaks is determined by intensity of defoliation as well as duration, in terms of consecutive years of defoliation, where widespread mortality of tree hosts contributes to the outbreak decline (Cooke et al. 2007). Within the context of the specific life history of an insect, the amount of defoliation is a function of number of insects. Number of insects, in turn, is affected by insect population factors, such as predators, parasitoids, mating success, etc. Defoliation is also influenced by factors that determine tree susceptibility: species composition, age, presence of non-host species, and site. The net effect of these interacting factors can be highly variable in time and space, with amount of defoliation by spruce budworm outbreaks ranging from one to $\sim 20$ years of annual moderate-severe defoliation (e.g., Gray and MacKinnon 2006; Zhao et al. 2014). In addition, contrasting defoliation outbreak patterns 
often occur in close spatial proximity; for example, Zhao et al. (2014) noted that most $66 \times 66 \mathrm{~km}$ cells across New Brunswick contained cumulative defoliation outbreak classes ranging from least to most severe. In comparing insects, there are large differences in outbreak periodicity, for example, a 35 -year cycle for spruce budworm versus a 10-year cycle for forest tent caterpillar. Periodicity and impacts of outbreaks and rotation time of the forest type are related if the insect causes major standreplacing outbreaks and also requires forest of a certain age for outbreaks to occur.

Spruce budworm larvae preferentially feed on the developing, current-year foliage and only eat older foliage after all the new foliage is consumed. This is also host species dependent, as the differing ability to back-feed on older foliage is an important factors in the relative vulnerability of their various hosts. If spruce budworm could back-feed as readily on spruce as it does on balsam fir (Abies balsamea (Linnaeus) Miller, Pinaceae), then it is quite possible that its impacts on spruce would be more severe than they are because there are many occasions when budworm density is well above the mean density that results in $100 \%$ defoliation of current-year foliage. The relationship between current annual defoliation and spruce budworm population level varies among years, and is typically determined annually by sampling during monitoring programmes, for example, Carter and Lavigne (1993). Such variability is attributable to population dynamics, phenology, natural enemies (predators and parasitoids), stage of outbreak, diseases, etc. An extensive permanent sample plot data set, with more than 27000 tree and 1100 stand measurements from 1984 to 1992 in New Brunswick, revealed a clear and consistent pattern of host species susceptibility to spruce budworm defoliation (Hennigar et al. 2008). Regardless of defoliation severity and other stand variables tested, white spruce, Picea glauca (Moench) Voss (Pinaceae); red spruce, Picea rubens Sargent; and black spruce, Picea mariana (Miller) Britton, Sterns, and Poggenburg, had $\sim 72 \%, 41 \%$, and $28 \%$ as much defoliation, respectively, as balsam fir (Hennigar et al. 2008). Balsam fir defoliation was a highly significant predictor of white, red, and black spruce defoliation, and $34 \%$ of the variation in defoliation of red-black spruce hybrids was explained by balsam fir defoliation and by spruce hybrid index, which quantifies the degree of red-black spruce introgression (Hennigar et al. 2008). Plant secondary metabolites such as terpenes and phenolics function as feeding deterrents or inhibit digestion of leaf material to influence larval feeding rate and development, thereby determining the severity of spruce budworm defoliation (Bauce et al. 2006; Kumbasli et al. 2011), and recent evidence suggests a genetic basis for spruce resistance (Mageroy et al. 2015). Balsam fir susceptibility to spruce budworm is reduced by the presence of hardwoods. Fir stands with higher hardwood content experience less spruce budworm defoliation (Su et al. 1996) when a threshold of 30-60\% hardwood composition (threshold depends on defoliation intensity) is exceeded (Croome 1970; Su et al. 1996; Needham et al. 1999; Campbell et al. 2008).

By examining forest tent caterpillar defoliation patterns in Québec, Charbonneau et al. (2012) found that a greater proportion of preferred host trees, such as trembling aspen, Populus tremuloides Michaux (Salicaceae), in the landscape increased defoliation severity and outbreak duration. This contrasts with Roland (1993) who found no impact of proportion of aspen on outbreak dynamics, once fragmentation was accounted for. On landscapes with a higher proportion of nonpreferred tree species, the likelihood of only a single year of forest tent caterpillar defoliation occurring was much greater than multi-year defoliation (Charbonneau et al. 2012). As well, middle-aged trees $(\sim 50$ years) were more likely to be defoliated than older trees (Charbonneau et al. 2012). However, Charbonneau et al. (2012) studied a single outbreak cycle, whereas Roland (1993) studied four outbreak cycles and covered a greater expanse of time and space. Analysis of forest tent caterpillar defoliation records from 1938 to 2002 in Ontario and Québec indicated that outbreaks recurred periodically and somewhat synchronously among regions. The most strongly periodic, large-scale, synchronised fluctuations occurred in three regions - northwestern Ontario, eastern Ontario/western Québec, and southeastern Québec (Cooke et al. 2012).

Outbreaks of defoliators are periodic, with distinct return intervals that vary by ecosystem. Knowledge of mean and variability of outbreak periodicity, as well as duration and severity, are 
key to long-term projection of effects on tree response and timber supply over one or more outbreaks. Spruce budworm outbreak periodicity was demonstrated using tree ring analysis in several early works (summarised in Blais 1983). Royama (1984) used a combination of information from Blais' previous tree ring analysis studies and spruce budworm population data to suggest an average cycle length of 35 years in New Brunswick (seven peaks over 210 years), and 38.5 years in Québec (eight peaks over 270 years). In contrast, in British Columbia, spruce budworm outbreaks occurred on average every 26 years, with five to six outbreaks in the past century in the northern regions of the district, while southern regions experienced between zero (the most southern sites) and four outbreaks (Burleigh et al. 2002). Western spruce budworm in southern British Columbia had a mean return interval of 28 years (95\% confidence interval $21-35$ years), with three to four outbreaks per century since the 1800s (Alfaro et al. 2014a).

\section{Growth reductions due to defoliation}

Step 2 of understanding insect impacts can be considered the characterisation of non-fatal effects on trees. Defoliation results in a number of physiological changes within a tree, rebalancing stem-wood, foliage, and root production in response to defoliation, as the tree attempts to survive and rebuild photosynthetic capacity. Reduced stem-wood production from insect outbreaks is well known, to the extent that sequences of narrow annual tree growth rings can be used to date past outbreaks. Although it was long believed that several years of defoliation were required before annual stem-wood growth was reduced, Piene (1980) demonstrated a reduction of up to $20 \%$ in the volume increment of balsam fir trees during the first year of defoliation. Volume growth, i.e., radial growth over the entire tree stem, of balsam fir is reduced by $25-56 \%$ in the second year of severe current defoliation (e.g., Batzer 1973; Baskerville and MacLean 1979; Piene 1980), and ultimately 75-90\% annual reductions occur (Batzer 1973; Baskerville and MacLean 1979; Ostaff and MacLean 1995; Erdle and MacLean 1999). As spruce budworm feeding is often most severe near the tops of trees, height growth usually ceases during years of severe defoliation. As a result of top-kill, heights of living trees may be reduced by $0.5-4.0 \mathrm{~m}$ during outbreaks (Baskerville and MacLean 1979). Alfaro et al. (1982, 1985) determined that volume loss per tree resulting from four western spruce budworm outbreaks in Douglas-fir, Pseudotsuga menziesii (Mirbel) Franco (Pinaceae), in British Columbia ranged from $8 \%$ to $17 \%$ and that the cumulative volume loss per tree for all four outbreaks averaged $44 \%$.

Many studies have quantified growth loss caused by eastern and western spruce budworm defoliation. Growth loss caused by spruce budworm defoliation has been quite consistent for balsam fir, typically reductions of $50-75 \%$ or more in radial or volume increment (13 studies reviewed by MacLean 1985). Growth loss caused by western spruce budworm defoliation has been more variable, both among studies and between different outbreak periods in the same study, with a range of $9-80 \%$ radial increment reductions (10 studies reviewed by MacLean 1985). The amount of spruce budworm-caused growth reduction typically differs among tree species, with balsam fir > spruce (e.g., Craighead 1924; Blais 1964; Solomon and Brann 1992; Ostaff and MacLean 1995), but this may primarily result from higher defoliation levels of fir than spruce (e.g., Hennigar et al. 2008). Defoliation of spruce can be severe during episodes of extremely high spruce budworm populations. Erdle and MacLean (1999) determined from permanent sample plot data that the relationships between tree diameter growth loss and cumulative defoliation were linear and similar for balsam fir, white spruce, and red-black spruce (the latter were combined because they hybridise and had fewer data). In contrast, relationships between reduced survival and cumulative defoliation were non-linear and differed among species and age classes (Erdle and MacLean 1999). For western spruce budworm, growth losses in grand fir, Abies grandis (Douglas ex Don) Lindley (Pinaceae), were much higher than in Douglas-fir (Williams 1967; Brubaker and Greene 1979).

There are many other studies of growth reduction caused by outbreaking insects, and reviewing all is beyond the scope of this paper, but I will include several examples. Cooke and Roland (2007) used dendro-ecological analysis to investigate trembling aspen responses to drought and defoliation by forest tent caterpillar in Ontario and 
found that the strongly decadal outbreaks resulted in growth reductions and were the main factor limiting aspen radial growth. Man et al. (2008) documented an unusually severe forest tent caterpillar outbreak in Ontario, in which diameter growth decreased by $65-70 \%$ during insect defoliation. Over the following six years, surviving trees recovered in terms of radial growth, but height growth did not recover due to continued crown dieback after defoliation ceased (Man et al. 2008). Iqbal et al. (2011a) quantified maximum radial growth reduction of balsam fir caused by hemlock looper, which feeds on all age-classes of foliage, as $10-15 \%$ with one year of moderatesevere defoliation, 35-40\% with two years of moderate defoliation, and about $50 \%$ with two years of severe defoliation. Growth recovered to pre-defoliation rates by five years after defoliation ceased in all severity classes. Growth reduction and recovery of black spruce were more variable and lower than for balsam fir, and white birch exhibited only minor $(<10 \%)$ radial growth reduction during the defoliation year or one year later (Iqbal et al. 2011a). In contrast, for balsam fir sawfly, which feeds on old (non-current) age classes of foliage, plots with one year of moderate defoliation showed $22 \%$ cumulative radial growth reduction and complete recovery to pre-defoliation growth increment after five years, while plots with 1-3 consecutive years of severe defoliation had mean cumulative growth reductions of $26-40 \%$ and did not recover to pre-defoliation levels even nine years after defoliation ceased (Iqbal et al. 2011b). Unthinned and thinned balsam fir plots responded similarly to balsam fir sawfly defoliation severity (Iqbal et al. 2011b).

Characteristic patterns of reduced annual ring width due to insects are routinely used to date past outbreak periods (e.g., Blais 1983). Magnussen and Alfaro (2012) calculated an average 10\% growth reduction from repeated defoliation of western hemlock, Tsuga heterophylla (Rafinesque) Sargent (Pinaceae), by the western hemlock looper, Lambdina fiscellaria lugubrosa (Hulst) (Lepidoptera: Geometridae), based on tree ring analyses.

\section{Tree mortality due to defoliation}

Step 3 of understanding insect impacts is characterisation of tree mortality, the most visible and severe result. For bark beetles such as mountain pine beetle, growth reduction is really not an issue, because bark beetles on lodgepole pine, Pinus contorta Douglas ex Loudon (Pinaceae), are obligate host killers, and they do this through mass-attack. With mountain pine beetle, mortality is highly probable on a per-tree basis (depending nonlinearly on rate of attack), and the tree either dies or survives with no impact. Mountain pine beetles attack pine trees by laying eggs under the bark and larvae mine the phloem and eventually cut off the tree's supply of nutrients. Mountain pine beetles also carry up to three species of symbiotic ophiotomatoid fungi that inhibit tree natural defenses against beetle attacks and also shut down water transport (Rice et al. 2007a, 2007b). Mountain pine beetle is generally specific about the age classes it attacks and kills, resulting in a clear impact on the age distribution of trees, even more so than with spruce budworm. Mountain pine beetle outbreaks can increase fire severity, with greater wind velocities associated with highly aggregated tree mortality and fire rateof-spread increased up to 2.7-fold immediately following the outbreak (Hoffman et al. 2015). Major disturbances attributable to mortality caused by severe spruce beetle outbreaks have also been identified in central British Columbia using tree ring analysis, in the late 1720s, 1810s-1820s, and 1960s-early 1980s (Zhang et al. 1999).

Many studies of tree mortality caused by spruce budworm outbreaks have been conducted in eastern North America, with 30 studies reviewed by MacLean $(1980,1985)$. The timing of mortality was consistent among outbreaks and locations, with the first trees usually dying after four to five years of severe defoliation (MacLean 1980). In less vulnerable, immature stands, it may take seven to eight years of severe defoliation for the first trees to die. Mortality caused by budworm usually ends about 12 years after the start of an outbreak, with $70-100 \%$ and $30-70 \%$ of the trees dead in mature and immature balsam fir stands, respectively (MacLean 1980). In western North America, Campbell et al. (2006) identified eight western spruce budworm outbreaks over the past 300 years, with considerable variation in timing and duration of outbreaks at the stand level, but synchronous outbreaks occurred in $~ 30-43$-year cycles. Outbreaks of eastern spruce budworm in white spruce stands in northeastern British Columbia (Burleigh et al. 2002) resulted in tree mortality, but this rapidly decreased following the 
initial decline of budworm populations in the southern stands (Alfaro et al. 2001). However, in northern sites mortality continued for several years, with trees succumbing to attack by secondary bark beetles and even woodborers (Burleigh et al. 2002).

Both tree species and age influence mortality. In summarising data from 100 plots from various studies, MacLean (1980) calculated an average mortality at the end of the spruce budworm outbreak of $85 \%$ in mature balsam fir stands, $42 \%$ in immature fir stands, $36 \%$ in mature spruce (mixed species) stands, and $13 \%$ in immature spruce stands. In comparison, mortality in 30 mature balsam fir plots in a severe spruce budworm outbreak from 1974 to 1985 in Cape Breton, Nova Scotia averaged 87\% (MacLean and Ostaff 1989). Mortality patterns observed in uncontrolled budworm outbreaks in different studies have generally been very consistent. Most data indicate that black spruce is less vulnerable (i.e., has a lower probability of mortality) than red or white spruce, which in turn are less vulnerable than balsam fir (MacLean 1980). Erdle and MacLean (1999) used two large, long-term permanent sample plot data sets ( $n=22350$ and 35500 tree measurements) to calibrate survival versus cumulative defoliation relationships for balsam fir and red-black spruce. Results showed: an increasing effect on survival reduction above $40 \%$ defoliation; an increasing effect of defoliation on survival reduction with increasing age; and a greater effect of defoliation on survival in fir than in spruce (Erdle and MacLean 1999). The reason for this species difference is not clear, but it could be attributable to the predisposition of fir, weakened by defoliation, to secondary mortality agents, rather than a differential mortality response to defoliation itself. Supporting this hypothesis are observations that shoe-string root rot, Armillaria mellea (Vahl ex Fries) Kummer (Tricholomataceae), occurred in $20 \%$ of balsam fir trees with $50-75 \%$ defoliation, in $50 \%$ of trees with $75-90 \%$ defoliation, and in 90\% of trees with $90-100 \%$ defoliation (Ostaff 1983). Spruce also has a stronger ability to re-foliate after defoliation than fir (Piene 1998). In British Columbia, likelihood of mortality of spruce caused by spruce budworm was related to defoliation intensity and duration, and to crown class, tree diameter, and $B t$ insecticide treatment (Magnussen et al. 2005).
Substantially less tree mortality occurs during western spruce budworm outbreaks than in spruce budworm outbreaks, with mortality concentrated in small trees (Carlson et al. 1983). Collis and Van Sickle (1978) found that mortality caused by a 1970-1974 western spruce budworm outbreak was $<1 \%$ in 16 of 20 stands, although Alfaro et al. (1982) observed that $39 \%$ of the trees, constituting only $12 \%$ of the basal area, were killed in one stand during the same outbreak. Differences between spruce budworm and western spruce budworm impacts could be due to differences in the insects, the host trees, or both. Mortality is related to the cumulative defoliation for both trees (Blais 1981; Alfaro et al. 1982; MacLean and Ostaff 1989; Erdle and MacLean 1999) and stands (Blais 1958; Batzer 1973; MacLean and Ostaff 1989). Various measures of cumulative defoliation have been calculated, including mean across all defoliated years, sum of each annual \% defoliation value (MacLean and Ostaff 1989; e.g., three years of $60 \%, 80 \%$, and $100 \%$ current year defoliation can be summed to $240 \%$, out of $300 \%$, and interpreted as equivalent to 2.4 age classes of foliage removed), and foliage age-class weighted (MacLean et al. 2001), and all are relatively similar. Using summed annual defoliation across years is intuitive for conifers with multiple age classes and it can be easily interpreted as number of age-classes of foliage removed.

Trembling aspen mortality caused by forest tent caterpillar is also associated with defoliation levels, particularly for trees in partial cut treatments (Man et al. 2008). Mortality during the three-year outbreak was 3-6\% annually, and in the subsequent six years after defoliation ceased, it increased to $9-13 \%$ annually, for a cumulative mortality of $54-76 \%$ (Man et al. 2008). This is unusually high mortality for a forest tent caterpillar outbreak, and the area was noted by Cooke et al. (2012) as an anomalous cluster resulting from a double-wave of defoliation that persisted from 1992 to 1999. Insect outbreaks, whether spruce budworm, forest tent caterpillar, or bark beetles, always have stochastic elements, and "unusually severe" tree mortality, substantially greater than the mean for that insect, tree species, and stand age, may arise whenever insect populations are extremely high, when defoliation persists longer than typical outbreaks, or if multiple tree stressors occur. 
Hemlock looper defoliation results in high mortality over a short period due to its feeding on all age classes of foliage. Relationships fit between per cent survival and years after defoliation showed that two years of severe (70-100\%) defoliation resulted in almost complete mortality for balsam fir measured 10 years later, versus 20-30\% mortality for black spruce and white birch (Iqbal et al. 2011a). Some severely defoliated trees would die earlier, but even trees with lower defoliation $(70 \%)$ succumbed after several years. In contrast, one to two years of moderate or one year of severe defoliation resulted in $\sim 40 \%$ mortality for balsam fir and no mortality of black spruce and white birch. Balsam fir sawfly defoliation caused no mortality in immature balsam fir 12 years after defoliation, but in mature fir, mortality was $72 \%$ in defoliated versus $18 \%$ in control, non-defoliated stands (Iqbal et al. 2011b). In British Columbia, Alfaro et al. (1999) reported severe mortality (51-96\%) due to western hemlock looper in stands composed of alpine fir (Abies lasiocarpa (Hooker) Nuttall (Pinaceae)), western hemlock, white spruce, and western red cedar (Thuja plicata Donn ex Don (Cupressaceae)).

Mountain pine beetle populations exist in one of four phases, defined in terms of population size relative to the abundance of available host: (1) endemic populations, principally in weakened or dead and often small-diameter trees; (2) incipientepidemic populations, which develop when largerdiameter host trees are successfully colonised; (3) epidemics, which exist at the landscape level, mainly as a consequence of large, highly contiguous areas of susceptible host and favourable weather conditions; and (4) post-epidemic (declining), due to adverse weather conditions or depletion of host, large-diameter, trees (Safranyik and Carroll 2006). Waring and Pitman (1985) examined the effects of physiological stress, via canopy density and nitrogen availability, on lodgepole pine susceptibility to mountain pine beetle attack. Where canopy density was reduced, either by thinning or by the insects, surviving trees significantly increased their resistance to attack and wood production per unit of leaf area (tree growth efficiency) over a three-year period. Improved nitrogen nutrition hastened tree recovery but did not prevent attacks by beetles until growth efficiencies exceeded $100 \mathrm{~g}$ of wood production per $\mathrm{m}^{2}$ of foliage. Other negative effects of mountain pine beetle outbreaks include water table rise, which can impact both pine and aspen productivity. Due to the nature of the interaction between the mountain pine beetle and its host trees, effective management requires detailed yearly surveys and prompt, thorough action against emerging incipient-epidemic infestations (Safranyik and Carroll 2006; Six et al. 2014). As of 2013, it was estimated that mountain pine beetle in British Columbia had killed a cumulative total of $723000000 \mathrm{~m}^{3}$ of timber over an area of 18300000 ha, that the outbreak peaked in 2005, and that the latest computer modelling projections indicated about $57 \%$ of the pine volume in the province may be killed by 2021 (British Columbia Ministry of Forests, Lands, and Natural Resource Operations 2013). For spruce beetle, during outbreaks in the 1970s and early 1980s in Alaska and Nova Scotia, $59 \%$ and $18 \%$, respectively, of the merchantable white spruce tree volume was killed (Ostaff and Newall 1981; Werner and Holsten 1983).

\section{Effects of spruce budworm outbreaks on productivity and stand development}

Step 4 of understanding insect impacts involves interpreting longer-term and indirect effects. The main long-term effects are changes in overstorey tree cover with mortality, altered competitive relationships between host and non-host species, regeneration and succession dynamics, and altered forest landscape age class distribution and species composition. Spruce budworm outbreaks kill overstorey trees and release advanced balsam fir and other regeneration, resulting in the insect having been termed a "super silviculturist" (Baskerville 1975). For host species, cessation of host seed production during defoliation is an important effect restricting host species to existing advanced regeneration, while non-host and competing shrubs and herbs can proliferate. In mixed host-hardwood stand types, non-host content $>40 \%$ results in lower host defoliation (Su et al. 1996). Non-host tree presence and the relative vulnerability of host species causes spruce budworm to vary between a stand-replacing and gap-creating disturbance as a function of the mix of host to non-host species (Bouchard et al. 2005; Campbell et al. 2008; Colford-Gilks et al. 2012). Hence, dynamics in these stand types are driven by species composition and outbreak severity. 
In shade tolerant hardwood-fir stands, the contrasting short and long-lived nature of balsam fir and tolerant hardwoods, plus vulnerability of fir, results in this stand type being transitional to tolerant hardwoods (Amos-Binks et al. 2010). However, in spruce-fir stands, the spruce-fir ratio of regeneration remains relatively stable over time following defoliation (Fye and Thomas 1963; Batzer and Popp 1985; Osawa 1994), implying relatively low fir regeneration mortality rates. Similar to the situation in fir stands, outbreak severity controls the invasion of intolerant hardwoods or shrubs, but this varies regionally (Bouchard et al. 2007).

Advances in computer and information gathering technology have made the evaluation of alternative management practices through model simulation a valuable tool for forest managers (MacLean 1996). Several models of effects of spruce budworm outbreaks on stand or landscape dynamics have been developed, for example, historical spruce budworm modelling of Holling and colleagues (Jones 1977; Clark et al. 1979), process-based stand model (Baskerville and Kleinschmidt 1981), timber supply modelling and forest management decisionmaking frameworks (e.g., Hall 1981), and empirical stand growth models (Steinman and MacLean 1994; Erdle and MacLean 1999). The spruce budworm decision support system (SBWDSS), originally developed conceptually by Erdle (1989) and refined into a software application by the Canadian Forest Service (MacLean et al. 2001), was developed to project effects of budworm outbreaks on tree growth, mortality, and timber supply, and to incorporate potential management actions into a decision-making framework. It is built upon empirical impact relationships, and uses annual defoliation data obtained from aerial surveys and user-defined defoliation scenarios. The model is deterministic and thus multiple defoliation scenarios are used but could eventually be coupled to population dynamic models as these improve. Cumulative defoliation is used to model tree growth reduction and mortality of stands in a geographic information system forest inventory database (MacLean et al. 2001). Hennigar et al. (2007) improved the SBWDSS modelling framework by integrating stand-level budworm volume impacts into a forest estate model, allowing pest management decisions such as foliage protection, harvest rescheduling, and salvage to be considered when maximising timber flows during a budworm outbreak. The latest iteration of the SBWDSS, termed Accuair ForPRO, integrates forest management planning and optimisation models with underlying tree impact information derived from pest management decision support tools (McLeod et al. 2012).

Landscape disturbance and succession models form a subset of forest landscape simulation models, identified by their explicit simulation of dynamic interactions between vegetation and disturbances in both space and time. These address the need to evaluate long-term risk by modelling long-term forest dynamics (Scheller and Mladenoff 2007). Implementation of defoliator disturbance regimes within the landscape disturbance and succession framework requires methods to: (1) define outbreak dynamics in time and space; (2) define the spatial distribution of resulting impacts; and (3) implement vegetation response to those impacts (Sturtevant et al. 2004).

Effects of altered stand dynamics, caused by insects, can be interpreted for a variety of indicators such as wildlife habitat, old forest, riparian buffer cover, viewscapes, and connectivity. Both the SBWDSS and landscape disturbance and succession models can be used to estimate effects of insect outbreaks on ecological indicators. As an example, Beaton et al. (2002) used the SBWDSS to examine effects of moderate and severe spruce budworm outbreak scenarios, occurring over a 15 -year period, on non-timber values including deer wintering areas, old spruce-fir habitat, buffers along watercourses and highways, future forest structure including species composition and diameter distribution, and conservation and unique areas. Deer wintering areas, defined to require softwood cover $\geqslant 50 \mathrm{~m}^{3} /$ ha, were projected to be reduced by $56 \%$ under a moderate and by $93 \%$ under a severe budworm outbreak scenario (Beaton et al. 2002). Old spruce-fir habitat, defined under the New Brunswick forest management regime, was projected to be reduced from 21900 ha of the 400000 ha study area without budworm, to only 9100 ha (58\% loss) or 3500 ha ( $84 \%$ loss), respectively, under moderate and severe budworm outbreak scenarios (Beaton et al. 2002). Conservation and unique areas represent an important feature for tourist visitors to the study area, and under moderate and severe budworm outbreak scenarios, $2 \%$ and $48 \%$ of these stands that were susceptible to spruce budworm were projected to lose more than $50 \%$ of 
their volume (Beaton et al. 2002). Buffer areas, which provide habitat connectivity, protection of waterways and visual aesthetics along provincial highways, were projected to lose $>30 \%$ of their volume for $17 \%$ and $42 \%$ of the susceptible buffer area under moderate and severe budworm outbreak projections (Beaton et al. 2002). Such simulations of effects of insect outbreaks on various non-timber values provide a basis for management decisions, such as using the biological insecticide Btk or reducing spruce/fir content of stands in advance of a budworm outbreak (Beaton et al. 2002).

Overall, the main effect of insect outbreak disturbance is change and forest renewal. But in contrast to fire, this renewal is tightly tied to host species vulnerability and to outbreak severity. For fire, there are clear differences in fire response to fuel types, especially hardwood versus coniferous, but these can be overcome by fire severity, which is closely related to weather, wind, and to a lesser extent, topography.

\section{Are anthropogenic changes amplifying effects of outbreaking insects?}

We can estimate past outbreak patterns and impacts, as in the previous Steps $1-4$, but are human and/or natural influences altering future outbreaks? The answer to this question is probably yes, but it depends on which insect, geographic locality, temporal and spatial scale, and the type of anthropogenic change. In addition, not all changes amplify effects - some probably dampen. As well, the evidence varies among insects and, except for mountain pine beetle, is somewhat open to interpretation.

Warmer winters under climate change have allowed mountain pine beetle to expand its range into areas where it has never before been a problem and where there were many prime host trees (Safranyik et al. 2010). Mountain pine beetle has also moved into jack pine, Pinus banksiana Lambert (Pinaceae), populations with a shift in the $-40{ }^{\circ} \mathrm{C}$ isotherm in the area of species overlap with lodgepole pine in northwestern Alberta (Cullingham et al. 2011). For defoliators, drought increases vulnerability to insect feeding, by causing higher carbohydrate levels in foliage (Mattson and Haack 1987). Jack pine budworm damage increases under drought (Volney and Fleming 2000), and secondary bark beetles kill drought-stressed trees (Raffa et al. 2008). However, increased disturbance, resulting from either increased fire or harvesting, will reset age-class structure to younger age classes and may decrease the risk of outbreaks of insects that tend to target older trees.

Effects of fire suppression on fuel build-up and changes in tree species composition is probably the clearest example where anthropogenic change has amplified disturbance effects, resulting in a significant increase in fire severity. Fire suppression over decades was thought to be a measure deemed to be good and environmentally sound, and there might well be a message here about critical evaluation of other well-intentioned efforts. Fire suppression has definitely changed forest types, with the area of lodgepole pine in western Canada tripled over the last century (Taylor and Carroll 2003). The current mountain pine beetle epidemic in western North America is to a large extent due to the biased age distribution and large area of contiguous susceptible forests, and beetle range expansion due to climate change just began the impact process (Taylor and Carroll 2003).

When considering effects of forest composition changes, the question arises concerning the baseline condition, is it the pre-European condition? Changes in species composition have occurred, but are variable. If there are more host species in some areas, then we can expect higher insect vulnerability and damage. Fire suppression, clearcutting, and insecticide use against spruce budworm have all tended to increase balsam fir in parts of eastern Canada (e.g., Blais 1983), which would result in more spruce budworm damage purely through increased area of the most vulnerable forest. It appears that the extent of spruce budworm outbreaks increased in the 20th century (Blais 1983; Kettela 1983), but evidence for any changes in periodicity and severity is less clear.

In 2011, in preparation for a conference presentation, I conducted an informal survey of knowledgeable colleagues regarding opinions about whether anthropogenic changes have amplified effects of outbreaking insects in Canada (Table 2). Questions included what evidence existed that anthropogenic changes have amplified insect outbreaks, and what mechanisms were involved? There were 35 responses from the 90 surveys I sent out, including 29 researchers, four provincial pest managers, and two forest managers. Locations of responders included British Columbia: seven, Alberta: four, Manitoba: 
Table 2. Results of an informal survey of 35 scientists and forest managers about their opinions of whether anthropogenic changes are amplifying ecological and economic effects of outbreaking insects in Canada.

Questions and answers from the survey

1. Are anthropogenic changes amplifying effects of indigenous outbreaking insects in Canada? Yes: 30, No: 1, No opinion: 0, Yes and No: 1

2. What evidence is there? For which insects?

MPB*: 12, SBW: 6, WSBW: 2, FTC: 3, BFS: 1, BHBW: 1.

3. What mechanisms are involved?

a) forest species composition and age structure changes

Yes: 25, No: 1, No opinion: 3

b) alteration of forest spatial configuration or patch size

Yes: 20, No: 1, No opinion: 8

c) broad climatic changes

Yes: 22, No: 1, No opinion: 9

4. Do you think that apparent "amplified" insect outbreak effects have occurred for:

a) MPB in British Columbia and Alberta

Yes: 27, No: 0, No opinion: 4

b) SBW outbreaks extent in eastern North America

Yes: 11, No: 6, No opinion: 11, Maybe: 5

c) SBW outbreaks observed in black spruce in Québec

Yes: 11, No: 2, No opinion: 19

d) unusually high mortality from FTC in Ontario

Yes: 7, No: 2, No opinion: 24

e) balsam fir sawfly outbreaks in thinned stands in Newfoundland

Yes: 9, No: 1, No opinion: 22

*Species abbreviations: MPB, mountain pine beetle; SBW, spruce budworm; WSWB, western spruce budworm; FTC, forest tent caterpillar; BFS, balsam fir sawfly; BHBW, blackheaded budworm (Acleris variana (Fernald), Lepidoptera: Tortricidae)

one, Ontario: three, Québec: seven, New Brunswick: 11, and the United States of America: two. Responses were near unanimous that anthropogenic changes are amplifying effects of outbreaking insects in Canada - 30 yes, one no, and one "yes-and-no" response (Table 2). Twelve responders believed that there was evidence of this for mountain pine beetle and six thought there was evidence for spruce budworm. Most responders thought that the mechanisms involved included forest species composition and age structure changes, alteration of forest spatial configuration or patch size, and broad climatic changes (Table 2). Nearly all responders agreed that apparent "amplified" insect outbreak effects have occurred for mountain pine beetle in British Columbia and Alberta, but opinions were mixed or "no opinion" for spruce budworm outbreak extent in eastern North America, spruce budworm outbreaks observed in black spruce in Québec, unusually high mortality from forest tent caterpillar in Ontario, and balsam fir sawfly outbreaks in thinned stands in Newfoundland and Labrador. Published evidence both prior to and since my 2011 survey corroborates the trends. The strongest evidence is for bark beetle systems of western North American. It is clear that latitudinal and elevation barriers have been breached for mountain pine beetle, and perhaps for spruce beetle (Carroll et al. 2003; Safranyik et al. 2010). Drought also plays a role in affecting susceptibility and vulnerability in bark beetle systems. There is some correlational evidence that compositional and land cover changes have influence, but not as strong as for climate drivers. Successful mountain pine beetle attack in Alberta in jack pine stands at the leading edge of the epidemic now provides a novel environment for mountain pine beetle, a potential risk that could be exacerbated by further climate change (Safranyik et al. 2010).

Effects of anthropogenic change on spruce budworm are still a matter of debate. The weight 
of evidence based on tree-ring studies, landscapescale contrasts, and food-web dynamics all suggests that changes in forest composition have played a role in changes in budworm outbreak dynamics. Spruce budworm populations rise and decrease irrespective of forest conditions, although human activities have resulted in less contiguous conifer forest but more balsam fir. In Maine, United States of America, Fraver et al. (2007) calculated a 67 year return interval for spruce budworm outbreaks, including the 1700s, long before human manipulation, which appeared longer than the more recent 35-40 year cycle, but this was based on a small study area and disregarded two minor outbreak peaks, which if included, gave a cycle frequency of 43 years. In Québec, even with abundant fir, the 1920s budworm outbreak caused light damage, but the 1970s outbreak was very severe (Bouchard and Pothier 2010), and the largest difference between these two outbreaks was climate rather than forest composition or insect population level. Historical analyses (Blais 1983) identified 21 budworm outbreaks from 1900 to 1983 versus nine from 1800 to 1900 . Earlier outbreaks were regional, but coalesced in the 20th century and increased in size, with the 1910s, 1940s, 1970s outbreak extents at 10000000,25000000 , and 55000000 ha, respectively. Paleo-ecological studies have shown spruce budworms present since at least 1520 years before present (Simard et al. 2002), with the greatest numbers of spruce budworm feces found in the upper $20 \mathrm{~cm}$ of the humus profiles, which equates to the 20th century, with fewer below. This may be due to lower spruce budworm populations before the 20th century or to intensification of decomposition with increasing humus depth (Simard et al. 2002). In New Brunswick, indications are that the 1870s spruce budworm outbreak was severe and stand-replacing (Etheridge et al. 2005). Blais (1981) suggested that every second budworm outbreak caused higher mortality, because a standreplacing outbreak results in a less vulnerable younger stand for the succeeding outbreak.

Long-term data on forest composition changes tend to be limited and localised. In Kings County, New Brunswick, comparing "witness trees", recorded by land surveyors at systematic grid distances across the area, from 1800 to forest composition in 1993, fir-spruce doubled from $25 \%$ of the forest to 50\% (Lutz 1997; Loo and Ives 2003). In the Miramichi watershed, New Brunswick, spruce-fir maintained dominance from 1800 to 2000 , and spruce-fir increased on $>50 \%$ area (Aube 2008). According to Loo and Ives (2003), balsam fir forests of Cape Breton have probably always been renewed by outbreaks of spruce budworm, but this situation has now spread to areas where historically the insect had a relatively minor impact.

Several recent studies have directly analysed effects of climate change on spruce budworm outbreaks. Future outbreaks of spruce budworm were predicted to be approximately six years longer with $15 \%$ greater defoliation, on average, using simulations of a global climate model for 2081-2100 (Gray 2008). Potential population growth rate for spruce budworm, based on physiological models using the 2041-2070 climate normal, predicted that outbreaks will shift northward and to higher elevations (Régnière et al. 2012). Gray (2013) projected that under a future (2011-2040) climate scenario the largest increases in outbreak duration and severity were predicted to occur on the Gaspé Peninsula and the north shore of the St. Lawrence River (Québec); the largest decreases in duration and severity in southern Ontario and along the Bay of Fundy in New Brunswick and Nova Scotia; and the predicted average changes in outbreak duration was -1.3 years and in outbreak severity was $-1.5 \%$ defoliation. Zhang et al. (2014) found that annual tree mortality increased with annual climate moisture index and decreased with annual minimum temperature, annual mean temperature, and the number of degree days below $0{ }^{\circ} \mathrm{C}$, and they inferred that tree mortality induced by insect outbreaks will decrease in eastern Canada under warming climate. In western Canada, Murdock et al. (2013) examined risks associated with western spruce budworm and spruce beetle outbreaks in a changing climate from biological and forest management perspectives. The analysis integrated projections of tree species suitability, pest outbreak risk, and bio-economic modelling, and investigated several methods of estimating pest outbreak risk. A simple climate envelope method based on empirically derived climate thresholds forecasted substantial changes in the distribution of outbreaks in British Columbia for two climate scenarios and both pests.

Roland (1993) provided evidence that forest fragmentation increases the length of forest tent 
caterpillar outbreaks. Although some have indicated that is inconsistent with what has actually happened, given 20 years without a forest tent caterpillar outbreak in central Alberta, this longer interval may well be an effect of northward drift in the envelope of optimal climate. A 2004-2014 forest tent caterpillar outbreak indeed materialised in Alberta, but about $300 \mathrm{~km}$ north of where forest tent caterpillar has previously been typically distributed. Aspen is sensitive to drought, and increased aspen mortality observed in Alberta and Ontario apparently resulted from interaction of forest tent caterpillar defoliation and drought, or drought alone (Candau et al. 2002). High temperatures and dry conditions aggravate the consequences of defoliation for aspen (Hogg et al. 2002), as does water table rise in wet areas (Perrette et al. 2014).

The latest balsam fir sawfly outbreak in Newfoundland was unprecedented in severity and duration, with the area affected equivalent to double the sum of all outbreaks in the previous 50 years and northward expansion of the area severely defoliated (Moreau 2006). The balsam fir sawfly outbreak has been attributed primarily to precommercial thinning of balsam fir, and both egg densities and defoliation were higher in thinned than unthinned stands (Ostaff et al. 2006). Thinning enhanced balsam fir sawfly survivorship (foliage quality) and reduced virus (Moreau et al. 2006). Another example is the unprecedented hemlock looper outbreak observed near RivièreSaint-Jean, Québec from 1998 to 1999.

Balsam woolly adelgid, Adelges piceae (Ratzeburg) (Hemiptera: Adelgidae), is an introduced species found in Maine in 1908, Nova Scotia 1910, New Brunswick 1942, other parts of Atlantic Canada, Québec, and British Columbia. It has caused significant mortality to balsam fir. In Maine, balsam woolly adelgid is moving inland, attacking and even killing fir where 10-20 years ago no evidence of this species existed. Mild winter temperatures are probably the cause of the expansion, but it is uncertain whether there is an ultimate anthropogenic cause.

To sum up, dynamics of insects are affected by the dynamics of forests, which include direct and indirect anthropogenic changes. For mountain pine beetle, range expansion and maintenance of high populations due to warmer winters and the increased availability of susceptible old host forest due to fire suppression are clear mechanisms of increased damage associated with anthropogenic changes (Safranyik et al. 2010). Spruce budworm changes are less clear but may include northern range expansion, and possible change in susceptibility (defoliation) with the currently observed severe damage in black spruce in Québec. There is less clear evidence for changes in spruce budworm population dynamics, but unusual outbreaks have been observed in the Québec North Shore north of Anticosti Island and in Goose Bay, Newfoundland and Labrador. I know of no clear evidence of changes in tree species vulnerability, of growth reduction and mortality resulting from a given level of defoliation. It remains unclear whether phenology of host trees and insects will change differentially, and whether forest vulnerability to insect feeding may increase if climate change stresses trees.

There are a number of caveats associated with interpretation of whether current and future environmental changes are altering forest insect dynamics. A balanced and unbiased assessment requires identification of both positive and negative cases, and a challenge is distinguishing true negative cases from false negative cases. Assessment of historic changes is inherently problematic as far more data are available for the 20th and 21st centuries than earlier. System responses may be correlated with anthropogenic activities, but correlation is not necessarily causation. Caution is required in interpreting emerging evidence that is subject to uncertainty, and is often based on short time series and spatially limited observations. There are also cautions about my informal survey, in that responses include a mix of "opinions" versus "knowledge" versus published, replicated data. But it may well be useful to seek areas of consensus of opinions, and then follow this by evaluating or collecting more evidence.

The climate is changing, and increased warming has been projected to increase fire severity in regions such as the Prairie provinces. Both positive and negative consequences will emerge, with harsher consequences in the north and lesser consequences in the south (Gray 2008, 2013; Régnière et al. 2012; Zhang et al. 2014). There is no consensus yet on the net difference. Range expansions of native insects northward are likely because of changing climate and of new exotic insects because of global trade. Stand replacing disturbances, such as large fires and mountain pine beetle outbreaks, may help forests to adapt to changing climates (Alfaro et al. 2014b). 
These outbreaks eliminate forests that grew under past climatic conditions and by promoting succession and regeneration, and over the long term give natural selection a chance to select trees that will be adapted to the new climates, but over the short term the shifts will be ecological. For fire-adapted tree species in British Columbia, elimination of the old forest canopy by stand-replacing fire triggers massive forest regeneration, while removal of mature lodgepole pine canopy by mountain pine beetle can result in forest transformation to different species unaffected by beetle (Alfaro et al. 2014b).

Mountain pine beetle range expansions have occurred, and climate change effects probably have greater impact than forest practices per se (Safranyik et al. 2010). Western spruce budworm also has exhibited a shift in the area over which outbreaks occur. Spruce budworm long-term trends are less clear, possibly longer, more severe outbreaks (Gray 2008) or reduced damage in southern areas due to unsuitable climate and northern range expansion. For spruce budworm, there are benefits to promoting spruce over balsam fir, mixedwood stands, and integration of some insecticide protection to reduce impacts. Another factor is that insect outbreaks (and fire) can have dramatic effects on forest carbon (e.g., Kurz et al. 2008; Dymond et al. 2010), with large-scale mortality resulting in a positive effect to climate change and a negative feedback to more damage. However, such effects may be temporary. Dead trees remain standing or as downed woody debris, for up to 30 years, and this carbon remains stored on site as recalcitrant carbon pools that are only slowly emitted to the atmosphere (Hansen 2014).

\section{Conclusions}

There is a huge body of literature about impacts of insect outbreaks in Canada, and this review provides examples rather than exhaustive coverage. There are five key messages that emerge from this review.

Impacts of insects on trees, notably reduced growth and survival during outbreaks, are a function of insect population and defoliation level. It is feasible to make short-term (annual) predictions of insect population level and defoliation based upon the current situation and population sampling, but long-term, multi-year population predictions are problematic. However, insect disturbances have shaped the current forest composition, structure, and age-class distribution, and if those outbreaks increase or decrease, those patterns will be altered.

Relationships between tree growth reduction, survival, and cumulative defoliation or beetle population level are available for some major insect species, and can be empirically determined using methods described by Erdle and MacLean (1999). Such relationships permit projection of effects of specified defoliation or beetle population levels on tree and stand dynamics. Tree-level or stand-level projections can also be used in timber supply and economic analyses, or decision support systems related to insecticide protection, harvest scheduling, or salvage actions.

Understanding effects of defoliation or beetle population levels on tree resources hinges on effects on stand dynamics: mortality, changes in interspecies competition, regeneration, and succession. Mortality introduces large pulses of standing and downed deadwood into ecosystems, which has important ecological functions (Harmon et al. 1986; Franklin et al. 1987). Effects of altered stand dynamics, caused by insects, can be interpreted for wildlife habitat types such as deer wintering areas and old forest habitat, riparian buffer cover, structure and composition of conservation and unique areas, viewscape aesthetics, and connectivity.

Climate change and anthropogenic changes are altering impacts of insect outbreaks. There is clear evidence that mountain pine beetle has expanded its range and that the severity of the outbreak is related to forest fire suppression resulting in more susceptible forest. Northward expansion of insect ranges is occurring now (e.g., mountain pine beetle and possibly spruce budworm and forest tent caterpillar) and this will likely increase in the future. Greater forest vulnerability can be expected if insect outbreaks coincide with drought or other stressors. In contrast, a generally younger age distribution resulting from more intensive management will tend to reduce damage. It is also possible that other insect species, not presently eruptive, may become eruptive if, for example, an extensive increase in host homogeneity occurs for a species otherwise normally occurring in mixed-wood stands.

Insect outbreaks are a major natural disturbance in our forests. We can better understand their effects and learn how best to adapt to or ameliorate damage through a combination of empirical permanent plot based studies, modelling, and manipulative experiments. 
I have several recommendations for future research related to this topic: (1) increased understanding of insect population dynamics that permits multi-year prediction of population levels and defoliation, which can be used as input into stand models and decision support; (2) remote sensing methods to accurately measure currentyear and cumulative defoliation levels of trees and stands; (3) better understanding of ecosystem processes and functions and how insects interact with these, to result in population dynamics, susceptibility, and vulnerability relationships; (4) elucidating mechanisms resulting in observed patterns, for example, of hardwood content reducing defoliation levels of host species by spruce budworm; (5) experimental trials to test pest management interventions, such as early intervention using intensive monitoring and use of Btk, Mimic, and/or semiochemicals to treat pre-defoliation but rising populations before defoliation in an attempt to prevent outbreaks (such a trial in underway for spruce budworm from 2014 to 2018 in New Brunswick: www. healthyforestpartnership.ca); and (6) quantification of susceptibility and vulnerability relationships for less-studied insect pest species, as are currently available for major species such as spruce budworm and mountain pine beetle.

\section{Acknowledgements}

The author appreciates the thorough reviews and many good suggestions made by two anonymous reviewers and the editors, which significantly improved the paper.

\section{References}

Alberta Sustainable Resource Development. 2007. Mountain pine beetle action plan. Publication T/152. Available from http://mpb.alberta.ca/Albertas Strategy/documents/MPB_action_plan.pdf [accessed 13 March 2015].

Alfaro, R.I., Berg, J., and Axelson, J. 2014a. Periodicity of western spruce budworm in southern British Columbia, Canada. Forest Ecology and Management, 315: 72-79.

Alfaro, R.I., Fady, B., Vendramin, G.G., Dawson, I.K., Fleming, R.A., Sáenz-Romero, C., et al. 2014b. The role of forest genetic resources in responding to biotic and abiotic factors in the context of anthropogenic climate change. Forest Ecology and Management, 333: 76-87.
Alfaro, R.I., Taylor, S., Brown, R.G., and Clowater, J.S. 2001. Susceptibility of northern British Columbia forests to spruce budworm defoliation. Forest Ecology and Management, 145: 181-190.

Alfaro, R.I., Taylor, S., Brown, G., and Wegwitz, E. 1999. Tree mortality caused by the western hemlock looper in landscapes of central British Columbia. Forest Ecology and Management, 124: 285-291.

Alfaro, R.I., Thomson, A.J., and Van Sickle, G.A. 1985. Quantification of Douglas-fir growth losses caused by western spruce budworm defoliation using stem analysis. Canadian Journal of Forest Research, 15: 5-9.

Alfaro, R.I., Van Sickle, G.A., Thomson, A.J., and Wegwitz, E. 1982. Tree mortality and radial growth losses caused by the western spruce budworm in a Douglas-fir stand in British Columbia. Canadian Journal of Forest Research, 12: 780-787.

Amos-Binks, L.J., MacLean, D.A., Wilson, J.S., and Wagner, R.G. 2010. Temporal changes in species composition of mixedwood stands in northwest New Brunswick: 1946-2008. Canadian Journal of Forest Research, 40: 1-12.

Aube, M. 2008. The pre-European settlement forest composition of the Miramichi River watershed, New Brunswick, as reconstructed using witness trees from original land surveys. Canadian Journal of Forest Research, 38: 1159-1183.

Axelson, J., Alfaro, R., and Hawkes, B. 2009. Influence of fire and mountain pine beetle on the dynamics of lodgepole pine stands in British Columbia, Canada. Forest Ecology and Management, 257: 1874-1882.

Axelson, J.N., Alfaro, R.I., and Hawkes, B.C. 2010. Changes in stand structure in uneven-aged lodgepole pine stands impacted by mountain pine beetle epidemics and fires in central British Columbia. The Forestry Chronicle, 86: 87-99.

Baskerville, G.L. 1975. Spruce budworm: super silviculturist. The Forestry Chronicle, 51: 138-140.

Baskerville, G. and Kleinschmidt, S. 1981. A dynamic model of growth in defoliated fir stands. Canadian Journal of Forest Research, 11: 206-214.

Baskerville, G.L. and MacLean, D.A. 1979. Budwormcaused mortality and 20-year recovery in immature balsam fir stands. Information Report M-X-102. Canadian Forest Service, Maritimes Forest Research Centre, Fredericton, New Brunswick, Canada.

Batzer, H.O. 1973. Net effect of spruce budworm defoliation on mortality and growth of balsam fir. Journal of Forestry, 71: 34-37.

Batzer, H.O. and Popp, M.P. 1985. Forest succession following a spruce budworm outbreak in Minnesota. The Forestry Chronicle, 61: 75-80.

Bauce, E., Kumbasli, M., Van Frankenhuyzen, K., and Carisey, N. 2006. Interactions among white spruce tannins, Bacillus thuringiensis subsp. kurstaki, and spruce budworm (Lepidoptera: Tortricidae), on larval survival, growth and development. Journal of Economic Entomology, 99: 2038-2047. 
Beaton, K.P., Porter, K.P., and MacKinnon, W.E. 2002. Extending the spruce budworm DSS: potential effects of budworm on non-timber values in the Fundy Model Forest [online]. Fundy Model Forest, Sussex, New Brunswick, Canada. Available from http://www.fundymodelforest.net/pdfs/publications/ management/Management_Planning_2002_Beaton_ $\%$ 20Extending\%20the $\% 20$ Spruce\%20Budwor.pdf [accessed 6 April 2015].

Blais, J.R. 1958. The vulnerability of balsam fir to spruce budworm attack in northern Ontario, with special reference to the physiological age of the tree. The Forestry Chronicle, 34: 405-422.

Blais, J.R. 1964. Account of a recent spruce budworm outbreak in the Laurentide Park region of Quebec and measures for reducing damage in future outbreaks. The Forestry Chronicle, 40: 313-323.

Blais, J.R. 1981. Mortality of balsam fir and white spruce following a spruce budworm outbreak in the Ottawa River watershed in Quebec. Canadian Journal of Forest Research, 11: 620-629.

Blais, J.R. 1983. Trends in the frequency, extent, and severity of spruce budworm outbreaks in eastern Canada. Canadian Journal of Forest Research, 13: 539-547.

Bouchard, M., Kneeshaw, D., and Bergeron, Y. 2005. Mortality and stand renewal patterns following the last spruce budworm outbreak in mixed forests of western Quebec. Forest Ecology and Management, 204: 297-313.

Bouchard, M., Kneeshaw, D., and Messier, C. 2007. Forest dynamics following spruce budworm outbreaks in the northern and southern mixedwoods of central Quebec. Canadian Journal of Forest Research, 37: 763-772.

Bouchard, M. and Pothier, D. 2010. Spatiotemporal variability in tree and stand mortality caused by spruce budworm outbreaks in eastern Quebec. Canadian Journal of Forest Research, 40: 86-94.

Bouchard, M., Pothier, D., and Ruel, J.C. 2009. Standreplacing windthrow in the boreal forests of eastern Quebec. Canadian Journal of Forest Research, 39: 481-487.

British Columbia Ministry of Forests, Lands, and Natural Resource Operations. 2013. Facts about B.C.'s mountain pine beetle [online]. Available from https://www.for.gov.bc.ca/hfp/mountain_pine_beetle/ Updated-Beetle-Facts_April2013.pdf [accessed 6 April 2015].

Brubaker, L.B. and Greene, S.K. 1979. Differential effects of Douglas-fir tussock moth and western spruce budworm defoliation on radial growth of grand fir and Douglas-fir. Canadian Journal of Forest Research, 9: 95-105.

Burleigh, J.S., Alfaro, R.I., Borden, J.H., and Taylor, S. 2002. Historical and spatial characteristics of spruce budworm Choristoneura fumiferana (Clem.) (Lepidoptera: Tortricidae) in northeastern British Columbia. Forest Ecology and Management, 168: 301-309.
Campbell, E.M., MacLean, D.A., and Bergeron, Y. 2008. The severity of budworm-caused growth reductions in balsam fir/spruce stands varies with the hardwood content of surrounding forest landscapes. Forest Science, 54: 195-205.

Campbell, R., Smith, D.J., and Arsenault, A. 2006. Multicentury history of western spruce budworm outbreaks in interior Douglas-fir forests near Kamloops, British Columbia. Canadian Journal of Forest Research, 36: 1758-1769.

Canadian Council of Forest Ministers. 2014. National forestry database: forest insects and forest fires statistics. Canadian Council of Forest Ministers. Natural Resources Canada, Canadian Forest Service, Ottawa, Ontario, Canada. Available from http://nfdp. ccfm.org/ [accessed 8 September 2014].

Candau, J.N., Abt, V., and Keatley, L. 2002. Bioclimatic analysis of declining aspen stands in northeastern Ontario. Forest Research Report 154. Ontario Forest Research Institute, Toronto, Ontario, Canada.

Candau, J.N. and Fleming, R.A. 2005. Landscape-scale spatial distribution of spruce budworm defoliation in relation to bioclimatic conditions. Canadian Journal of Forest Research, 35: 2218-2232.

Candau, J.N., Fleming, R.A., and Hopkin, A.A. 1998. Spatiotemporal patterns of large-scale defoliation caused by the spruce budworm in Ontario since 1941. Canadian Journal of Forest Research, 28: 1-9.

Carlson, C.E., Fellin, D.G., and Schmidt, W.C. 1983. The western spruce budworm in northern Rocky Mountain forests: a review of ecology, insecticidal treatments and silvicultural practices. In Management of second growth forests: the state of knowledge and research needs. Edited by J. O'Loughlin and R.D. Pfister. Montana Forest Conservation Experiment Station, University Montana, Missoula, Montana, United States of America. Pp. 76-103.

Carroll, A.L., Taylor, S.W., Régnière, J., and Safranyik, L. 2003. Effect of climate change on range expansion by the mountain pine beetle in British Columbia. In Mountain pine beetle symposium: challenges and solutions. Edited by T.L. Shore, J.E. Brooks, and J.E. Stone. Information Report BC-X-399. Canadian Forest Service, Pacific Forestry Centre, Victoria, British Columbia, Canada. Pp. 223-232.

Carter, N.E. and Lavigne, D.R. 1993. Protection spraying against spruce budworm in New Brunswick, 1992. New Brunswick Department of Natural Resources and Energy, Timber Management Branch, Forest Pest Management Section, Fredericton, New Brunswick, Canada.

Charbonneau, D., Lorenzetti, F., Doyon, F., and Mauffette, Y. 2012. The influence of stand and landscape characteristics on forest tent caterpillar (Malacosoma disstria) defoliation dynamics: the case of the 1999-2002 outbreak in northwestern Quebec. Canadian Journal of Forest Research, 42: 1827-1836.

Clark, W.C., Jones, D.D., and Holling, C.S. 1979. Lessons for ecological policy design: a case study of ecosystem management. Ecological Modeling, 7: 1-53. 
Colford-Gilks, A.K., MacLean, D.A., Kershaw, J.A., and Béland, M. 2012. Growth and mortality of balsam fir-and spruce-tolerant hardwood stands as influenced by stand characteristics and spruce budworm defoliation. Forest Ecology and Management, 280: 82-92.

Collis, D.G. and Van Sickle, G.A. 1978. Damage appraisal cruises in spruce budworm defoliation stands of Douglas-fir in 1977. Pest Report BC-P-19. Canadian Forest Service, Pacific Forest Research Centre, Victoria, British Columbia, Canada.

Cooke, B.J., MacQuarrie, C.J.K., and Lorenzetti, F. 2012. The dynamics of forest tent caterpillar outbreaks across east-central Canada. Ecography, 35: 422-435.

Cooke, B.J., Nealis, V.G., and Régnière, J. 2007. Insect defoliators as periodic disturbances in northern forest ecosystems. In Plant disturbance ecology: the process and the response. Edited by E.A. Johnson and K. Miyanishi. Elsevier Academic Press, Burlington, Massachusetts, United States of America. Pp. 487-525.

Cooke, B.J. and Roland, J. 2007. Trembling aspen responses to drought and defoliation by forest tent caterpillar and reconstruction of recent outbreaks in Ontario. Canadian Journal of Forest Research, 37: 1586-1598.

Craighead, F.C. 1924. Studies on the spruce budworm (Cacoecia fumiferana (Clem.)). Part II. General bionomics and possibilities of prevention and control. Canada Department of Agriculture, Technical Bulletin, 37: 28-91.

Croome, G.C.R. 1970. A trial of selection management in a mature fir-spruce-birch forest. The Forestry Chronicle, 46: 317-321.

Cullingham, C.I., Cooke, J.E.K., Dang, S., Davis, C.S., Cooke, B.J., and Coltman, D.W. 2011. Mountain pine beetle host-range expansion threatens the boreal forest. Molecular Ecology, 20: 2157-2171.

Dymond, C., Neilson, E., Stinson, G., Porter, K., MacLean, D.A., Gray, D., et al. 2010. Future spruce budworm outbreak may create a carbon source in eastern Canadian forests. Ecosystems, 13: 917-931.

Erdle, T.A. 1989. Concept and practice of integrated harvest and protection design in the management of eastern spruce fir forests. Ph.D. thesis. University of New Brunswick, Fredericton, New Brunswick, Canada.

Erdle, T.A. and MacLean, D.A. 1999. Stand growth model calibration for use in forest pest impact assessment. The Forestry Chronicle, 75: 141-152.

Etheridge, D.A., MacLean, D.A., Wagner, R.G., and Wilson, J.S. 2005. Changes in landscape composition and stand structure from 1945-2002 on an industrial forest in New Brunswick, Canada. Canadian Journal of Forest Research, 35: 1965-1977.

Fleming, R.A., Candau, J.N., and McAlpine, R.S. 2002. Landscape-scale analysis of interactions between insect defoliation and forest fire in Central Canada. Climatic Change, 55: 251-272.
Franklin, J.F., Shugart, H.H., and Harmon, M.E. 1987. Tree death as an ecological process. BioScience, 37: 550-556.

Fraver, S., Seymour, R.S., Speer, J.H., and White, A.S. 2007. Dendrochronological reconstruction of spruce budworm outbreaks in northern Maine, USA. Canadian Journal of Forest Research, 37: 523-529.

Fye, R.E. and Thomas, J.B. 1963. Regeneration of balsam fir and spruce about fifteen years following release by spruce budworm attack. The Forestry Chronicle, 39: 385-397.

Gray, D.R. 2008. The relationship between climate and outbreak characteristics of the spruce budworm in eastern Canada. Climatic Change, 87: 361-383.

Gray, D.R. 2013. The influence of forest composition and climate on outbreak characteristics of the spruce budworm in eastern Canada. Canadian Journal of Forest Research, 43: 1181-1195.

Gray, D.R. and MacKinnon, W.E. 2006. Outbreak patterns of the spruce budworm and their impacts in Canada. The Forestry Chronicle, 82: 550-561.

Gray, D.R. and MacKinnon, W.E. 2007. Historical spruce budworm defoliation records adjusted for insecticide protection in New Brunswick, 1965-1992. Journal of the Acadian Entomological Society, 3: 1-6.

Gray, D.R., Régnière, J., and Boulet, B. 2000. Analysis and use of historical patterns of spruce budworm defoliation to forecast outbreak patterns in Quebec. Forest Ecology and Management, 127: 217-231.

Hall, T.H. 1981. Forest management decision-making; art or science? The Forestry Chronicle, 57: 233-238.

Hansen, E.M. 2014. Forest development and carbon dynamics after mountain pine beetle outbreaks. Forest Science, 60: 476-488.

Harmon, M.E., Franklin, J.F., Swanson, F.J., Sollins, P., Gregory, S.V., Lattin, J.D., et al. 1986. Ecology of coarse woody debris in temperate ecosystems. In Advances in ecological research. Volume 15. Edited by A. MacFadyen and E.D. Ford. Academic Press, Orlando, Florida, United States of America. Pp. 133-302.

Hennigar, C.R. and MacLean, D.A. 2010. Spruce budworm and management effects on forest and wood product carbon for an intensively managed forest. Canadian Journal of Forest Research, 40: 1736-1750.

Hennigar, C.R., MacLean, D.A., Porter, K.B., and Quiring, D.T. 2007. Optimized harvest planning under alternative foliage-protection scenarios to reduce volume losses to spruce budworm. Canadian Journal of Forest Research, 37: 1755-1769.

Hennigar, C.R., MacLean, D.A., Quiring, D.T., and Kershaw, J.A. 2008. Differences in spruce budworm defoliation among balsam fir and white, red and black spruce. Forest Science, 54: 158-166.

Hoffman, C.M., Linn, R., Parsons, R., Sieg, C., and Winterkamp, J. 2015. Modeling spatial and temporal dynamics of wind flow and potential fire behavior following a mountain pine beetle outbreak in a lodgepole pine forest. Agricultural and Forest Meteorology, 204: 79-93. 
Hogg, E.H., Brandt, J.P., and Kochtubajda, B. 2002. Growth and dieback of aspen forests in northwestern Alberta, Canada, in relation to climate and insects. Canadian Journal of Forest Research, 32: 823-832.

Iqbal, J., MacLean, D.A., and Kershaw, J.A. 2011 a. Impacts of hemlock looper defoliation on growth and survival of balsam fir, black spruce and white birch in Newfoundland, Canada. Forest Ecology and Management, 261: 1106-1114.

Iqbal, J., MacLean, D.A., and Kershaw, J.A. 2011 b. Balsam fir sawfly defoliation effects on survival and growth quantified from permanent plots and dendrochronology. Forestry, 84: 349-362.

Jones, D.D. 1977. The budworm site model. In Proceedings of a conference on pest management. 25-29 October 1976. CP-77-6. International Institute of Applied Systems Analysis, Laxenburg, Austria. Pp. 91-155.

Kettela, E.G. 1983. A cartographic history of spruce budworm defoliation 1967 to 1981 in eastern North America. Information Report DPC-X-14. Canadian Forest Service, Ottawa, Ontario, Canada.

Kettela, E.G. 1995. Insect control in New Brunswick, 1974-1989. In Forest insect pests in Canada. Edited by J.A. Armstrong and W.G.H. Ives. Canadian Forest Service, Ottawa, Ontario, Canada. Pp. 656-665.

Kumbasli, M., Bauce, É., Rochefort, S., and Crépin, M. 2011. Effects of tree age and stand thinning related variations in balsam fir secondary compounds on spruce budworm Choristoneura fumiferana development, growth and food utilization. Agricultural and Forest Entomology, 13: 131-141.

Kurz, W.A., Dymond, C.C., Stinson, G., Rampley, G.J., Neilson, E.T., Carroll, A.L., et al. 2008. Mountain pine beetle and forest carbon feedback to climate change. Nature, 452: 987-990.

Loo, J. and Ives, N. 2003. The Acadian forest: historical condition and human impacts. The Forestry Chronicle, 79: 462-474.

Lutz, S.G. 1997. Pre-European settlement and present forest composition in King's County, New Brunswick, Canada. M.Sc.F. thesis. University of New Brunswick, Fredericton, New Brunswick, Canada.

MacLean, D.A. 1980. Vulnerability of fir spruce stands during uncontrolled spruce budworm outbreaks: a review and discussion. The Forestry Chronicle, 56: 213-221.

MacLean, D.A. 1985. Effects of spruce budworm outbreaks on forest growth and yield. In Recent advances in spruce budworms research. Edited by C.J. Sanders, R.W. Stark, E.J. Mullins, and J. Murphy. Canadian Forest Service, Ottawa, Ontario, Canada. Pp. 148-175.

MacLean, D.A. 1996. The role of a stand dynamics model in the spruce budworm decision support system. Canadian Journal of Forest Research, 26: 1731-1741.

MacLean, D.A., Erdle, T.A., MacKinnon, W.E., Porter, K.B., Beaton, K.P., Cormier, G., et al. 2001. The spruce budworm decision support system: forest protection planning to sustain long-term wood supplies. Canadian Journal of Forest Research, 31: 1742-1757.
MacLean, D.A. and Ostaff, D.P. 1989. Patterns of balsam fir mortality caused by an uncontrolled spruce budworm outbreak. Canadian Journal of Forest Research, 19: 1087-1095.

Mageroy, M.H., Parent, G., Germanos, G., Giguère, I., Delvas, N., Maaroufi, H., et al. 2015. Expression of the $\beta$-glucosidase gene $P g \beta g l u$ - 1 underpins natural resistance of white spruce against spruce budworm. The Plant Journal, 81: 68-80.

Magnussen, S. and Alfaro, R.I. 2012. Linking aerial survey data of forest insect defoliation and tree ring data to estimate forest level growth losses. Dendrochronologia, 30: 287-294.

Magnussen, S., Alfaro, R.I., and Boudewyn, P. 2005. Survival-time analysis of white spruce during spruce budworm defoliation. Silva Fennica, 39: 177-189.

Man, R., Kayahara, G.J., Rice, J.A., and MacDonald, G.B. 2008. Response of trembling aspen to partial cutting and subsequent forest tent caterpillar defoliation in a boreal mixedwood stand in northeastern Ontario, Canada. Canadian Journal of Forest Research, 38: 1349-1356.

Mattson, W. and Haack, R. 1987. Role of drought in outbreaks of plant-eating insects. BioScience, 37: 110-118.

McLeod, I.M., Lucarotti, C.J., Hennigar, C.R., MacLean, D.A., Holloway, A.G.L., Cormier, G.A., et al. 2012. Advances in aerial application technologies and decision support for integrated pest management. In Integrated pest management and pest control. Edited by S. Soloneski and M.L. Larramendy. InTech Open Access Publisher, Rijeka, Croatia. Pp. 651-668.

Moreau, G. 2006. Past and present outbreaks of the balsam fir sawfly in western Newfoundland: an analytical review. Forest Ecology and Management, 221: 215-219.

Moreau, G., Eveleigh, E.S., Lucarotti, C.J., and Quiring, D.T. 2006. Ecosystem alteration modifies the relative strengths of bottom-up and top-down forces in a herbivore population. Journal of Animal Ecology, 75: 853-861.

Murdock, T.Q., Taylor, S.W., Flower, A., Mehlenbacher, A., Montenegro, A., Zwiers, F.W., et al. 2013. Pest outbreak distribution and forest management impacts in a changing climate in British Columbia. Environmental Science and Policy, 26: 75-89.

Needham, T., Kershaw, J.A. Jr., MacLean, D.A., and $\mathrm{Su}$, Q. 1999. Effects of mixed stand management to reduce impacts of spruce budworm defoliation on balsam fir stand-level growth and yield. Northern Journal of Applied Forestry, 16: 19-24.

Osawa, A. 1994. Seedling responses to forest canopy disturbance following a spruce budworm outbreak in Maine. Canadian Journal of Forest Research, 24: 850-859.

Ostaff, D.P. 1983. A wood quality study of dead and dying balsam fir - the incidence of Armillaria root rot. Technical Note 82. Canadian Forest Service, Maritimes Forest Research Centre, Fredericton, New Brunswick, Canada. 
Ostaff, D.P. and MacLean, D.A. 1995. Patterns of balsam fir foliar production and growth in relation to defoliation by spruce budworm. Canadian Journal of Forest Research, 25: 1128-1136.

Ostaff, D.P. and Newell, W.R. 1981. Spruce mortality in Nova Scotia caused by the spruce beetle Dendroctonus rufipennis Kby. Information Report M-X-122. Canadian Forest Service, Maritimes Forest Research Centre, Fredericton, New Brunswick, Canada.

Ostaff, D.P., Piene, H., Quiring, D.T., Moreau, G., Farrell, J.C.G., and Scarr, T. 2006. Influence of pre-commercial thinning of balsam fir on defoliation by the balsam fir sawfly. Forest Ecology and Management, 223: 342-348.

Payette, S., Bhiry, N., Delwaide, A., and Simard, M. 2000. Origin of the lichen woodland at its southern range limit in eastern Canada: the catastrophic impact of insect defoliators and fire on the sprucemoss forest. Canadian Journal of Forest Research, 30: $288-305$.

Péch, G. 1993. Fire hazard in budworm-killed balsam fir stands on Cape Breton Highlands. The Forestry Chronicle, 69: 178-186.

Perrette, G., Lorenzetti, F., Moulinier, J., and Bergeron, Y. 2014. Site factors contribute to aspen decline and stand vulnerability following a forest tent caterpillar outbreak in the Canadian clay belt. Forest Ecology and Management, 323: 126-137.

Piene, H. 1980. Effects of insect defoliation on growth and foliar nutrients of young balsam fir. Forest Science, 26: 665-673.

Piene, H. 1998. Spruce budworm defoliation-foliage production: differences between white spruce and balsam fir. In Population dynamics, impacts, and integrated management of forest defoliating insects. Edited by M.L. McManus and A.M. Liebhold. General Technical Report NE-247. United States Department of Agriculture, Forest Service, Hamden, Connecticut, United States of America. Pp. 247-252.

Raffa, K.F., Aukema, B.H., Bentz, B.J., Carroll, A.L., Hicke, J.A., Turner, M.G., et al. 2008. Cross-scale drivers of natural disturbances prone to anthropogenic amplification: the dynamics of bark beetle eruptions. BioScience, 58: 501-517.

Régnière, J., St-Amant, R., and Duval, P. 2012. Predicting insect distributions under climate change from physiological responses: spruce budworm as an example. Biological Invasions, 14: 1571-1586.

Rice, A.V., Thormann, M.N., and Langor, D.W. 2007a. Mountain pine beetle-associated blue-stain fungi cause lesions on jack pine, lodgepole pine, and lodgepole $\times$ jack pine hybrids in Alberta. Canadian Journal of Botany, 85: 307-315.

Rice, A.V., Thormann, M.N., and Langor, D.W. 2007b. Virulence of and interactions among mountain pine beetle-associated blue-stain fungi on two pine species and hybrids. Canadian Journal of Botany, 85: 316-323.
Roland, J. 1993. Large-scale forest fragmentation increases the duration of tent caterpillar outbreak. Oecologia, 93: 25-30.

Royama, T. 1984. Population dynamics of the spruce budworm Choristoneura fumiferana. Ecological Monographs, 54: 429-462.

Royama, T., MacKinnon, W.E., Kettela, E.G., Carter, N.E., and Hartling, L.K. 2005. Analysis of spruce budworm outbreak cycles in New Brunswick, Canada, since 1952. Ecology, 86: 1212-1224.

Safranyik, L. and Carroll, A.L. 2006. The biology and epidemiology of the mountain pine beetle in lodgepole pine forests. In The mountain pine beetle: a synthesis of biology, management, and impacts on lodgepole pine. Edited by L. Safranyik and W.R. Wilson. Canadian Forest Service, Pacific Forestry Centre, Victoria, British Columbia, Canada. Pp. 3-66.

Safranyik, L., Carroll, A.L., Régnière, J., Langor, D.W., Riel, W.G., Shore, T.L., et al. 2010. Assessment of range expansion of the mountain pine beetle in the boreal forest. The Canadian Entomologist, 142: 415-442.

Scheller, R.M. and Mladenoff, D.J. 2007. An ecological classification of forest landscape simulation models: tools and strategies for understanding broadscale forested ecosystems. Landscape Ecology, 22: 491-505.

Simard, I., Morin, H., and Potelle, B. 2002. A new paleoecological approach to reconstruct long-term history of spruce budworm outbreaks. Canadian Journal of Forest Research, 32: 428-438.

Six, D.L., Biber, E., and Long, E. 2014. Management for mountain pine beetle outbreak suppression: does relevant science support current policy? Forests, 5: 103-133.

Solomon, D.S. and Brann, T.B. 1992. Ten-year impact of spruce budworm on spruce-fir forests of Maine. General Technical Report NE-165. United States Department of Agriculture, Forest Service, Northeastern Forest Experiment Station, Radnor, Pennsylvania, United States of America.

Steinman, J.R. and MacLean, D.A. 1994. Predicting effects of defoliation on spruce fir stand development: a management oriented growth and yield model. Forest Ecology and Management, 69: 283-298.

Stocks, B.J. 1987. Fire potential in the spruce budworm-damaged forests of Ontario. The Forestry Chronicle, 63: 8-14.

Stocks, B.J., Mason, J.A., Todd, J.B., Bosch, E.M., Wotton, B.M., Amiro, B.D., et al. 2003. Large forest fires in Canada, 1959-1997. Journal of Geophysical Research, 108: 8149. doi:10.1029/ 2001JD000484.

Sturtevant, B.R., Gustafson, E.J., Li, W., and He, H.S. 2004. Modeling biological disturbances in LANDIS: a module description and demonstration using spruce budworm. Ecological Modeling, 180: $153-174$. 
Su, Q., MacLean, D.A., and Needham, T.D. 1996. The influence of hardwood content on balsam fir defoliation by spruce budworm. Canadian Journal of Forest Research, 26: 1620-1628.

Taylor, S.W. and Carroll, A.L. 2003. Disturbance, forest age, and mountain pine beetle outbreak dynamics in BC: a historical perspective. In Mountain pine beetle symposium: challenges and solutions. Edited by T.L. Shore, J.E. Brooks, and J.E. Stone. Information Report BC-X-399. Canadian Forest Service, Pacific Forestry Centre, Victoria, British Columbia, Canada. Pp. 41-51.

Taylor, S.L. and MacLean, D.A. 2009. Legacy of insect defoliators: increased wind-related mortality two decades after a spruce budworm outbreak. Forest Science, 55: 256-267.

Volney, W.J.A. and Fleming, R.A. 2000. Climate change and impacts of boreal forest insects. Agriculture, Ecosystems and Environment, 82: 283-294.

Waring, R.H. and Pitman, G.B. 1985. Modifying lodgepole pine stands to change susceptibility to mountain pine beetle attack. Ecology, 66: 889-897.
Werner, R.A. and Holsten, E.H. 1983. Mortality of white spruce during a spruce beetle outbreak on the Kenai Peninsula in Alaska. Canadian Journal of Forest Research, 13: 96-101.

Williams, C.B. 1967. Spruce budworm damage symptoms related to radial growth of grand fir, Douglas-fir, and Engelmann spruce. Forest Science, 13: 274-285.

Zhang, Q., Alfaro, R.I., and Hebda, R.J. 1999. Dendroecological studies of tree growth, climate and spruce beetle outbreaks in Central British Columbia, Canada. Forest Ecology and Management, 121: 215-225.

Zhang, X., Lei, Y., Ma, Z., Kneeshaw, D., and Peng, C. 2014. Insect-induced tree mortality of boreal forests in eastern Canada under a changing climate. Ecology and Evolution, 4: 2384-2394.

Zhao, K., MacLean, D.A., and Hennigar, C.R. 2014. Spatial variability of spruce budworm defoliation at different scales. Forest Ecology and Management, 328: $10-19$. 